University of New Hampshire

University of New Hampshire Scholars' Repository

$12-2012$

\title{
In the Wake of the Spill: Environmental Views Along the Gulf Coast
}

Lawrence C. Hamilton

University of New Hampshire - Main Campus, lawrence.hamilton@unh.edu

Thomas G. Safford

University of New Hampshire, tom.safford@unh.edu

Jessica D. Ulrich

University of New Hampshire

Follow this and additional works at: https://scholars.unh.edu/soc_facpub

Part of the Sociology Commons

\section{Comments}

This is the pre-peer reviewed version of the following article: Hamilton, L. C., Safford, T. G. and Ulrich, J. D. (2012), In the Wake of the Spill: Environmental Views Along the Gulf Coast. Social Science Quarterly, 93: 1053-1064, which has been published in final form at https://dx.doi.org/10.1111/j.1540-6237.2012.00840.x. This article may be used for non-commercial purposes in accordance with Wiley Terms and Conditions for Self-Archiving.

\section{Recommended Citation}

Hamilton, L. C., Safford, T. G. and Ulrich, J. D. (2012), In the Wake of the Spill: Environmental Views Along the Gulf Coast. Social Science Quarterly, 93: 1053-1064. doi: 10.1111/j.1540-6237.2012.00840.x

This Article is brought to you for free and open access by the Sociology at University of New Hampshire Scholars' Repository. It has been accepted for inclusion in Sociology Scholarship by an authorized administrator of University of New Hampshire Scholars' Repository. For more information, please contact Scholarly.Communication@unh.edu. 
AUTHORS' DRAFT. Final version published in:

Social Science Quarterly (2012) 93(4):1053-1064. doi: 10.1111/j.1540-6237.2012.00840

\title{
IN THE WAKE OF THE SPILL ENVIRONMENTAL VIEWS ALONG THE GULF COAST
}

\author{
Lawrence C. Hamilton \\ Department of Sociology \\ University of New Hampshire \\ Thomas G. Safford \\ Department of Sociology \\ University of New Hampshire \\ Jessica D. Ulrich \\ Department of Sociology \\ University of New Hampshire
}

\section{Acknowledgments}

The CERA Gulf survey was supported by grants from the Carsey Institute and the Vice Provost for Research at the University of New Hampshire. Sampling and interviews were done by the UNH Survey Center. We thank two reviewers for their comments on an earlier draft.

\begin{abstract}
Objectives: We analyze patterns in environmental views of Gulf Coast residents, in the wake of the 2010 oil spill. To what extent do spill-related and other environmental views vary with individual characteristics, personal experience with the spill, or characteristics of place?
\end{abstract}

Methods: About 2,000 residents of selected coastal regions in Louisiana and Florida were interviewed by telephone in late summer 2010 .

Results: One quarter of the respondents said that their environmental views had changed as a result of the spill. Despite reporting more change, more spill effects, and greater threats from climate-induced sealevel rise, Louisiana respondents were less likely to support a deepwater moratorium, alternative energy, or resource conservation.

Conclusions: Results are consistent with real effects from the spill. Differences between Louisiana and Florida respondents are not explained by spill effects or individual characteristics, however. The patterns reflect bio-physical differences of the coastlines that shaped their socioeconomic development.

\section{Introduction}

On April 20, 2010, an explosion at the Deepwater Horizon oil drilling platform off Louisiana killed 11 workers and touched off the largest marine oil spill in history. Oil from a ruptured pipe poured into the deep sea for three months, televised live via robot-operated cameras. Regulatory failures together with shortcuts in safety equipment and procedures precipitated this accident, but in the immediate 
aftermath questions of blame took second place to worries about the scale of the disaster. By mid-June, oil was washing ashore on wetlands, barrier islands and beaches of Louisiana, Mississippi, Alabama, and the Florida Panhandle. An estimated 4.4 million barrels escaped before the wellhead was successfully capped on July 15, and closure ensured by a relief well on September 19 (Crone and Tolstoy 2010).

As oil poured into the sea during the summer of 2010, economic and political waves spread ahead of the oil. Much of the Gulf quickly was closed to fishing. The Obama administration declared a 6month moratorium on deepwater drilling in the Gulf on May 27. Oil interests challenged the moratorium in court, winning an injunction on June 22. The administration imposed a narrower moratorium on July 12 against deepwater wells that used a blowout preventer, subsequently lifted ahead of schedule on October 12. A nominally more lasting decision on December 1 extended for seven years the longstanding ban on oil development in the eastern Gulf (around Florida) and the Atlantic seaboard - thus reversing plans to end the eastern Gulf ban that had been announced just weeks before the spill began.

While the drilling moratorium and ongoing spill disrupted oil and fishing industries, Gulf Coast tourism suffered as well. Coastal property owners in Florida reported cancellations of vacation rentals for the peak holiday season, whether or not they had seen any oil. Economic losses caused by the spill are disputed - by one estimate, $\$ 23$ billion over a three-year period for the tourism industry alone (Oxford Economics 2010). A fund set up by British Petroleum to compensate residents, fishermen and business owners paid out $\$ 3.3$ billion by February 2011, with many claims denied and others still pending (Weber 2011). Environmentalists raised concerns of massive non-economic damage too, much of it offshore. Although surface oil slicks ultimately proved less extensive than feared, the long-term ecological consequences of subsurface oil and chemical dispersants remain under study and unknown (Lovett 2010).

Social impacts remain under study as well (e.g., Abramson et al. 2010; Goidel and Kirzinger 2010). We began our research with a baseline survey of 2,000 Gulf Coast Louisiana and Florida residents in late summer 2010, just after initial capping of the leak. The survey elicited perceptions of spill impacts, the deepwater moratorium, and other environmental issues. Views on environmental issues varied with background, employment, and belief factors as expected. Net of these, we also found strong place effects, reflecting characteristics of places or the environments themselves. Gramling and Freudenburg (1996) examined how coastal Louisiana and Florida environments channelized economic and social development. Their socio-ecological explanation fits the pattern of Louisiana-Florida differences in our survey.

\section{Background}

Historically, Louisiana and Florida took opposite paths on offshore oil development. Louisiana welcomed oil and today benefits greatly, roughly $\$ 65$ billion per year. Florida, where intense opposition led to banning offshore development, instead earns a similar amount from tourism (Cave 2010). The stark contrast in public support highlights economic and cultural differences, which in turn are shaped by differences in coastal geography (Gramling and Freudenburg 1996).

In their 1994 comparative study, Freudenburg and Gramling examined the divergent public responses to offshore oil development in Louisiana and California. Offshore oil promised economic benefits to both places, yet from its early 20th-century beginnings it was greeted with open arms in Louisiana and strenuous opposition in California. These contrasting reactions sprang from different environmental as well as social and historical conditions. Louisiana's marshy coastal topography permits few people or roads near the coast, quite the opposite of California. Seawater muddied by Mississippi River silt, and the lack of beaches or views, further limit the amenity value of Louisiana's coast. Shallow water and silt bottoms make it easy for fisheries to coexist with oil platforms in the Gulf, while steep and rocky slopes make this harder off California. Thus, important social and economic values conflict with offshore oil development in California, but not in Louisiana. Freudenburg and Gramling noted parallels 
between California and Florida, where a similarly accessible and beloved coastline engendered similar opposition to oil, and encouraged other livelihoods. In a subsequent article they took the socio-ecological comparison further, contrasting Louisiana with south Florida (Gramling and Freudenburg 1996).

Environmental differences set the stage for socioeconomic divergence. Louisiana's coastline supported extractive but not amenity development, giving rise to government, workforce, and social organization adapted to extractive industries. In California or Florida, on the other hand, a broader range of opportunities supported less specialized development. Gramling and Freudenburg (2006:456) conclude:

“to a large extent coastal Louisiana has become not just 'adapted to' but 'dependent on' its offshore petroleum activities - and it is difficult to be too critical in evaluating an activity from which one has benefitted, particularly if the activity is one on which one remains dependent for any hopes of comparable, future prosperity."

In recent years, public opinion in Florida had grown somewhat more favorable to offshore oil development. Besides economic incentives, one reason for this shift had been the relatively good safety record of offshore oil in the Gulf - prior to the Deepwater Horizon disaster. With that safety record shattered, however, Florida misgivings about offshore development resurfaced. One might expect new misgivings in Louisiana as well. Our survey found, indeed, that more Louisiana residents reported personal impacts from the spill, and more said that their views on other environmental issues had changed as a result. Despite adverse spill effects, however, a large majority of coastal Louisiana residents (unlike those in Florida) opposed steps to halt deepwater drilling until new safety could be implemented.

\section{CERA and the Gulf Coast Survey}

Rural residents' views regarding their communities and local environmental issues have been examined through a series of regional surveys under the Community and Environment in Rural America (CERA) initiative. From 2007 through 2010, random-sample telephone interviews took place with more than 16,000 individuals in rural regions of 14 states (Hamilton et al. 2008; Safford and Hamilton 2010; Ulrich 2010). One common theme has been repeated confirmation of place effects: significant variations in environmental views that are not explained by individual characteristics, but follow characteristics of places or the environments themselves (Hamilton and Keim 2009; Hamilton et al. 2010).

Adapting CERA's design to breaking news in the Gulf, in summer 2010 we surveyed coastal areas of Louisiana and the Florida Panhandle. This survey combined core questions from CERA with new ones specifically about the Gulf spill, and about environment-related views in its aftermath.

Telephone interviews were completed with 1,000 residents of Plaquemines and Terrebonne Parishes in Louisiana, and 1,000 more living in Bay, Gulf, and Franklin Counties, Florida (Figure 1). We selected these places based on their location in areas directly impacted by the oil spill as well as their connection to ocean-related economic activities such as oil exploration, commercial and sport fishing, and tourism.

Of the five counties or parishes surveyed, only Gulf and Franklin are considered nonmetropolitan. Despite its proximity to New Orleans, Plaquemines Parish remains sparsely populated and largely rural in character (NOAA 2005b). Bay County and Terrebonne Parish have much larger populations and densities. Like more rural areas, however, they depend economically on natural resources.

Historically important to coastal counties of the Florida panhandle, the timber industry and more recently the commercial fishing industry are in states of decline. Over time the timber industry has become almost obsolete, while despite its decline, commercial fisheries remain important to the region's economy, job market and culture. One out of every four jobs in Franklin County is related to the fishing industry (Gaither and Worthen 2010). New economic drivers such as coastal tourism and recreational fishing are becoming increasingly important and attracting new residents including many retirees (NOAA 
2005a). Franklin County gained the most population over the past decade (15\%). Growth in Bay and Gulf counties was more modest, 11 and 8\% respectively (Census Bureau 2010). The Florida panhandle has been a hotspot for population growth in the Gulf of Mexico region (Crossett et al. 2004).

Both Terrebonne and Plaquemines Parishes remain dependent upon commercial and recreational fisheries as an important source of livelihood (NOAA 2005b). However, oil production and associated services, not tourism, is the other main driver of the region's economy. In Terrebonne Parish, for example, about $17 \%$ of employees and $26 \%$ of payroll in 2008 could be linked directly to the oil and gas industry (Census Bureau 2008). A "social multiplier" effect (Freudenburg and Gramling 1994) makes the total impact even larger. Population in Terrebonne Parish has grown 5\% over the past decade, while Plaquemines Parish, where Hurricane Katrina made landfall in 2005 and destroyed much of the housing stock, lost almost $22 \%$ of its population (Census Bureau 2010).

All counties and parishes surveyed tend to vote Republican. In the 2008 Presidential election, the McCain vote ranged from 63 to $70 \%$. Moreover, the region has grown increasingly conservative over the past decade (NYT 2008). The majority of both Florida and Louisiana populations live in coastal counties, where they are vulnerable to ocean-related disasters (Crossett et al. 2004). Florida and Louisiana have received more than other states in spill-related claims (Alderstein 2010).

Interviews took place from July 29 through September 30. This window coincided with a quieter but not yet settled period between the successful capping that ended most of the oil flow (July 14), and completion of a final relief well (September 19). To check whether the window might have spanned a shift in public opinion, we analyzed key response variables by date, but found no evidence of systematic change. Probability weights were calculated following methods described by Lee and Forthofer (2006) to adjust for known effects of sampling design (household size, county population) and differential response (age, sex, race). The overall response rate, defined by the American Association for Public Opinion Research's RR4 standard (AAPOR 2006), was 41\% in Florida and 38\% in Louisiana.

\section{Views of Energy and Environment}

Table 1 lists seven questions on environment-related issues. The first two ask about the impacts of environmental events (oil spill, extreme weather) on the respondent's own family or community. Conserve poses a general question about the tradeoff between using resources for jobs or conserving them for the future. Changed asks whether respondents' views on other environmental issues changed as a result of the oil spill. Searise inquires about the local threat of sea-level rise due to global warming or climate change. Moratorium and alternative raise possible short- or long-term policy options that might reduce the risk of future spills, and arguably (in the case of alternative) help to mitigate sea-level, extreme weather, and other risks from greenhouse-induced climate change.

A pattern of seemingly contradictory differences emerges when we break down responses by state (Figure 2). Louisiana residents more often reported that the spill had major effects on themselves or their family. These would include not just oil industry impacts but post-spill fishing closures, which disrupted livelihoods in Plaquemines and Terrebonne Parishes. These parishes also have been hit hard by recent hurricanes including Katrina, and they contain more land barely above sea level today (EPA 2010). Geographical vulnerability and recent experiences explain why coastal Louisiana residents more often reported major effects from extreme weather, and regarded sea-level rise as a threat. Our Florida counties, on the other hand, are mostly a bit farther above sea level, and depend less on fishing or oil. Spill impacts would more often have been felt economically through effects on tourism.

Although Louisiana residents experienced more harm from the spill, and are more exposed to flooding, they were less likely to favor a moratorium on deepwater drilling, increased use of alternative energy, or conservation of natural resources. The deepwater moratorium was meant to reduce the risk of further oil spills in the immediate future. Alternative energy development or conservation might have 
longer-term benefits, reducing the risk both of oil spills and increased flooding. Thus, we see a contrast between Louisiana residents' greater exposure to environment-related disasters and weaker support for these environmental protections.

\section{Oil Spill, Weather and Place Effects}

Table 2 presents results from weighted logit regression of environment-related views on background or social-position factors, including those generally comprising the "social bases of environmental concern" (e.g., Jones and Dunlap 1992, Van Liere and Dunlap 1980). Two variables indicate whether respondents or family members work in the tourism or oil and gas industries. Predictors also include spill or extreme weather impacts, the "jobs vs. conservation" item, and whether respondents said their views had changed as a result of the spill.

The changed item is treated as a dependent variable in the first column of Table 2. People reporting personal spill impacts, or major local effects from extreme weather events, were more likely (odds ratios significantly greater than 1) to say their environmental views had changed. Conserve also predicts changed. Although part of its effect might be reciprocal, keeping conserve among the predictors provides some control for pre-existing environmental beliefs. Age, race, income, politics, employment sector, and state made no significant difference. Women and less educated respondents more often reported having changed their views. This education effect, the only one in Table 2, makes an interesting counterpoint to work elsewhere showing that better-educated respondents tend to be more polarized on environmental topics (e.g., Hamilton 2011; McCright \& Dunlap 2011). In Table 2, we see that bettereducated respondents less often said that their views changed following the spill.

Elsewhere in Table 2, changed is treated as an independent variable. Net of 12 other predictors, changed shows significant, plausible effects. Respondents who said the spill had changed their views tended to express greater concern about sea level, more support for a moratorium, and prioritized alternative energy over increased oil exploration. The resource-conservation question conserve also shows effects in the expected direction. Independent effects of changed and conserve strengthen the case for interpreting changed as reflecting some degree of real change, net of pre-existing environmental beliefs.

Personal spill and weather impacts tended to raise concern about sea-level but had no effect on views about the moratorium or alternative energy. Direct economic interests influence opinions in unsurprising ways: people connected with the oil and gas industry opposed a moratorium and preferred increased oil exploration to alternative energy development. Tourism jobs had no significant effects.

Gender, age, race and income show affects that are consistent in direction though not always significant. Political party exhibits consistently strong, significant effects. Republicans were less likely to perceive a threat to their communities from sea-level rise, to support a deepwater moratorium, or to favor alternative energy. These results confirm in a new context the partisan gap regarding virtually all environment-related topics that have been reported by other recent studies.

Politically, our Florida and Louisiana subsamples are indistinguishable — 53 vs. 52\% Republican, and 33 vs. $32 \%$ Democrat. Neither politics nor other factors explains their gap in environmental views. Louisiana respondents more often saw sea level rise as a serious threat ( $84 \%$ higher odds). That perception reflects their greater physical vulnerability (more subsiding and very low land), and their state's recent experience with multiple hurricanes (Katrina, Rita, Gustav) resulting in flooding of coastal communities. At the same time, Louisiana respondents were far less likely to favor a deepwater moratorium ( $82 \%$ lower odds) or alternative energy development (68\% lower).

\section{Discussion}


The Deepwater Horizon spill dramatized environmental risks of offshore oil development, and deepwater development in particular. In its immediate aftermath, a temporary pause in deepwater drilling pending a review and new safety measures seemed reasonable to most Americans (NYT 2010). For many Gulf residents, however, the economic costs of such a pause outweighed the benefits of greater safety-even while tens of thousands of barrels per day were flowing into Gulf waters, and jobs in fishing and tourism were shut down.

If disasters teach any lessons, then experience with the Gulf oil spill might be expected to alter opinions about the need for environmental protection. About one fourth of our respondents said that as a result of the spill their views on other environmental issues such as global warming or protecting wildlife had changed. Such self-reports must be interpreted with caution, but our analytical results are consistent with some degree of real change. Effects from the changed variable remain significant, and have the expected direction, even controlling for 12 other factors including political party and conservation beliefs. A planned follow-up study will later seek objective evidence of change beyond the aftermath of the spill.

Earlier stages of CERA research highlighted a number of ways in which "place matters." Environmental perceptions are influenced by relationships between community and environment, not just individual cognitive or social factors. Examples include effects of winter warming on perceptions about climate change (Hamilton and Keim 2009), effects of population growth and unemployment rates on support for environmental protection (Hamilton et al. 2010), or effects of resource vs. amenity-based development on concern about pollution (Safford and Hamilton 2020). Our Gulf Coast survey adds another example where community relationships to the natural world affect views on environmental issues, both immediate and long-term.

The pattern of responses from coastal Louisiana, where many more people reported effects from the spill, extreme weather, or threats from climate-related sea-level rise- - but fewer supported a deepwater moratorium, alternative energy, or resource conservation-reflects socioeconomic development around oil and gas. Specialization has been channeled partly by physical characteristics of the Louisiana coastline itself. Florida's Gulf Coast geography supported development in different directions, so today there are fewer oil-related jobs but much amenity development also at risk from spills and climate effects. From a perspective shaped by this different coastal landscape, steps that might reduce such risks while slowing oil and gas development appeared more attractive.

\section{References}

AAPOR. 2006. Standard Definitions: Final Disposition of Case Codes and Outcome Rates for Surveys, 4th edition. Lenexa, KS: American Association for Public Opinion Research.

Abramson, D., I. Redlener, T. Stehling-Ariza, J. Sury, A. Banister and Y.S. Park. 2010. "Impact on children and families of the Deepwater Horizon oil spill: Preliminary findings of the coastal population impact study." National Center for Disaster Preparedness, Research Brief 2010:8. New York: Columbia University.

Alderstein, D. 2010. "Nearly \$24 million paid in BP related claims." The Apalachicola and Carrabelle Times, December $2^{\text {nd }}$.

Cave, D. 2010. "Florida skips offshore oil binge but still pays." The New York Times, June 14, http://www.nytimes.com/2010/06/13/us/13florida.html?hpw. 
Census Bureau. 2008. "2008 County business patterns (NAICS).” Retrieved May 11, 2011

(http://censtats.census.gov/cgi-bin/cbpnaic/cbpsel.pl)

Census Bureau. 2010. "State and County Quickfacts." Washington, DC: U.S. Department of Commerce. Retrieved December 8, 2010 (http://quickfacts.census.gov/qfd/states/30/30031.html)

Crone, T.J. and M. Tolstoy. 2010. "Magnitude of the 2010 Gulf of Mexico oil leak." Science 29 October:634.

Crossett, K. M., T. J. Culliton, P. C. Wiley and T. R. Goodspeed. 2004. "Population trends along the coastal United States: 1980-2008." National Oceanic and Atmospheric Association. Retrieved December 9, 2010 (http://www.oceanservice.noaa.gov/programs /mb/supp_cstl_population.html).

EPA. 2010. "Maps of lands vulnerable to sea level rise - On the Gulf Coast." Environmental Protection Agency http://epa.gov/climatechange/effects/coastal/slrmaps gulf.html

Freudenburg, W.R. and R. Gramling. 1994. Oil in Troubled Waters: Perceptions, Politics, and the Battle over Offshore Drilling. NY: State University of New York Press.

Gaither, C.J. and H.D Worthen. 2010. "The Influence of race and class on resident response to economic restructuring in Franklin County, Florida, USA." Social and Cultural Geography 11(5): 451-474.

Goidel, K. and A. Kirzinger. 2010. "The view from the coast: A survey of 924 coastal residents on the 2010 Gulf oil spill.” Baton Rouge, LA: Reilly Center for Median \& Public Affairs, Louisiana State University.

Gramling, R. and W.R. Freudenburg. 1996. "Crude, Coppertone, and the coast: Developmental channelization and constraint of alternative development opportunities." Society and Natural Resources 9:483-506.

Gramling, R. and W.R. Freudenburg. 2006. "Attitudes toward offshore oil development: A summary of current evidence." Ocean and Coastal Management 49:442-461.

Hamilton, L.C., L.R. Hamilton, C.M. Duncan and C.R. Colocousis. 2008. "Place Matters: Challenges and Opportunities in Four Rural Americas.” Durham, NH: Carsey Institute, University of New Hampshire.

Hamilton, L.C. and B.D. Keim. 2009. "Regional variation in perceptions about climate change. International Journal of Climatology 29(15):2348-2352.

Hamilton, L.C., C.R. Colocousis and C.M. Duncan. 2010. "Place effects on environmental views." Rural Sociology 75(2):326-347.

Jones, R.E. and R.E. Dunlap. 1992. "The social bases of environmental concern: Have they changed over time?” Rural Sociology 57:28-47.

Lovett, R.A. 2010. “Oil spill’s toxic tradeoff.” Nature doi:10.1038/news.2010.597. 
McCright, A.M. and R.E. Dunlap. 2011. "The politicization of climate change and polarization in the American public's views of global warming, 2001-2010.” Sociological Quarterly 52:155-194.

NOAA. 2005a. Identifying Communities Associated with the Fishing Industry Along the Florida Gulf Coast, Final Report. St. Petersburg, FL: U.S. Department of Commerce, National Oceanic and Atmospheric Administration Fisheries, Southeast Regional Office.

NOAA. 2005b. Identifying Communities Associated with the Fishing Industry in Louisiana, Final Report. St. Petersburg, FL: U.S. Department of Commerce, National Oceanic and Atmospheric Administration Fisheries, Southeast Regional Office.

NYT. 2008. "Election Results 2008 - President Map." New York Times. Retrieved December 8, 2010 (http://elections.nytimes.com/2008/results/president/map.html).

NYT. 2010. "Views on the oil spill." New York Times, June 21. http://www.nytimes.com/interactive/2010/06/22/us/20100622-poll-chart.html?ref=us

Oxford Economics. 2010. "Potential impacts of the Gulf oil spill on tourism." Report prepared for the U.S. Travel Association. Retrieved December 142010 http://www.ustravel.org/sites/default/files/page/2009/11/Gulf_Oil_Spill_Analysis_Oxford_Economics_7 10.pdf

Safford, T.G. and L.C. Hamilton. 2010. "Ocean views: Coastal environmental problems as seen by Downeast Maine residents.” New England Policy Brief No. 3. Durham, NH: Carsey Institute, University of New Hampshire.

Ulrich, J. 2010. "How Yoopers see the future of their communities: Why residents leave or stay in Michigan's upper Peninsula Policy.” Policy Brief No. 17. Durham, NH: Carsey Institute, University of New Hampshire.

Van Liere, K.D. and R.E. Dunlap. 1980. "The social bases of environmental concern: A review of hypotheses, explanations and empirical evidence." Public Opinion Quarterly 44(2):181-197.

Weber, H.R. 2011. "Gulf should recover from spill by 2012, funds czar says.” Boston Globe, February 3:A2. 
Table 1: CERA 2010 survey questions related to the Gulf Coast environment, with weighted response percentages.

Spill

Would you say that the BP Horizon oil spill has had major effects (36\%), minor effects (31\%), or no effects $(32 \%)$ on you and your family's economic well-being? Percent "major effects" graphed in Figure 2 .

\section{Weather}

Have unusual or extreme weather-related events had major effects $(31 \%)$, minor effects $(31 \%)$, or no effect $(36 \%)$ on your family or community over the past 5 years? Percent "major effects" graphed in Figure 2.

\section{Conserve}

For the future of your community, do you think it is more important to use natural resources to create jobs (33\%), to conserve natural resources for future generations (34\%), or are jobs and conservation both equally important (17\%)? Percent "conserve" graphed in Figure 2.

\section{Changed}

Have your views about other environmental issues such as global warming or protecting wildlife changed as a result of the oil spill? ( $25 \%$ yes, $72 \%$ no) Percent "yes" graphed in Figure 2.

\section{Searise}

Does rise in sea level due to global warming or climate change pose a serious threat to you or your community in the future? (43\% yes, $48 \%$ no) Percent "yes" graphed in Figure 2.

\section{Moratorium}

Do you favor (39\%) or oppose (51\%) a moratorium that would halt deepwater drilling, until new safety requirements are met? Percent "favor" graphed in Figure 2.

\section{Alternative}

Which do you think is more important, increased exploration and drilling for oil in the U.S. (36\%), or increased use of solar, wind and alternative energy sources $(55 \%)$ ? Percent "alternative" graphed in Figure 2. 
Table 2: Predictors of individual views related to the Gulf Coast environment. Odds ratios from weighted logit regression, with $t$ tests based on linearized standard errors.

\begin{tabular}{|c|c|c|c|c|}
\hline \multirow[b]{2}{*}{ Predictor } & \multicolumn{4}{|c|}{ Dependent Variable } \\
\hline & Changed & Searise & Moratorium & Alternative \\
\hline Spill impacts & $1.80^{* *}$ & $1.80^{* *}$ & 1.23 & 1.10 \\
\hline Weather & $1.96^{* * *}$ & $2.18^{* * *}$ & 1.24 & 1.52 \\
\hline Conserve resources & $1.59^{*}$ & $1.91^{* * *}$ & $2.20^{* * *}$ & $1.97^{* * *}$ \\
\hline Changed views & & $1.76^{* *}$ & $1.56^{*}$ & $1.82^{* *}$ \\
\hline Gender (female) & $1.63^{* *}$ & $1.40^{*}$ & 1.13 & $1.61^{* *}$ \\
\hline Age (in years) & 1.00 & .99 & $.98^{* *}$ & $.98^{* *}$ \\
\hline Race (nonwhite) & 1.14 & 1.36 & 1.17 & $.60^{*}$ \\
\hline Education ( $1 \leq \mathrm{HS}, 4$ grad) & $.80^{*}$ & .95 & 1.03 & 1.15 \\
\hline Income $(1<20 k, 6$ >120k) & .91 & .95 & .95 & $.85^{*}$ \\
\hline Party (1 Dem, 3 Rep) & .85 & $.65^{\star * *}$ & $.52^{* * *}$ & $.43^{\star * *}$ \\
\hline Oil job & 1.42 & 1.11 & $.47^{*}$ & $.40^{* * *}$ \\
\hline Tourism job & 1.19 & .49 & $1.55)$ & 1.47 \\
\hline Louisiana & .90 & $1.84^{* *}$ & $.18^{* * *}$ & $.32)^{\star * *}$ \\
\hline $\begin{array}{ll}\text { estimation sample } \\
* * \quad p<.05 \\
* * \quad p<.01 \\
* * * \quad p<.001\end{array}$ & $n=1,467$ & $n=1,467$ & $n=1,467$ & $n=1,320$ \\
\hline
\end{tabular}




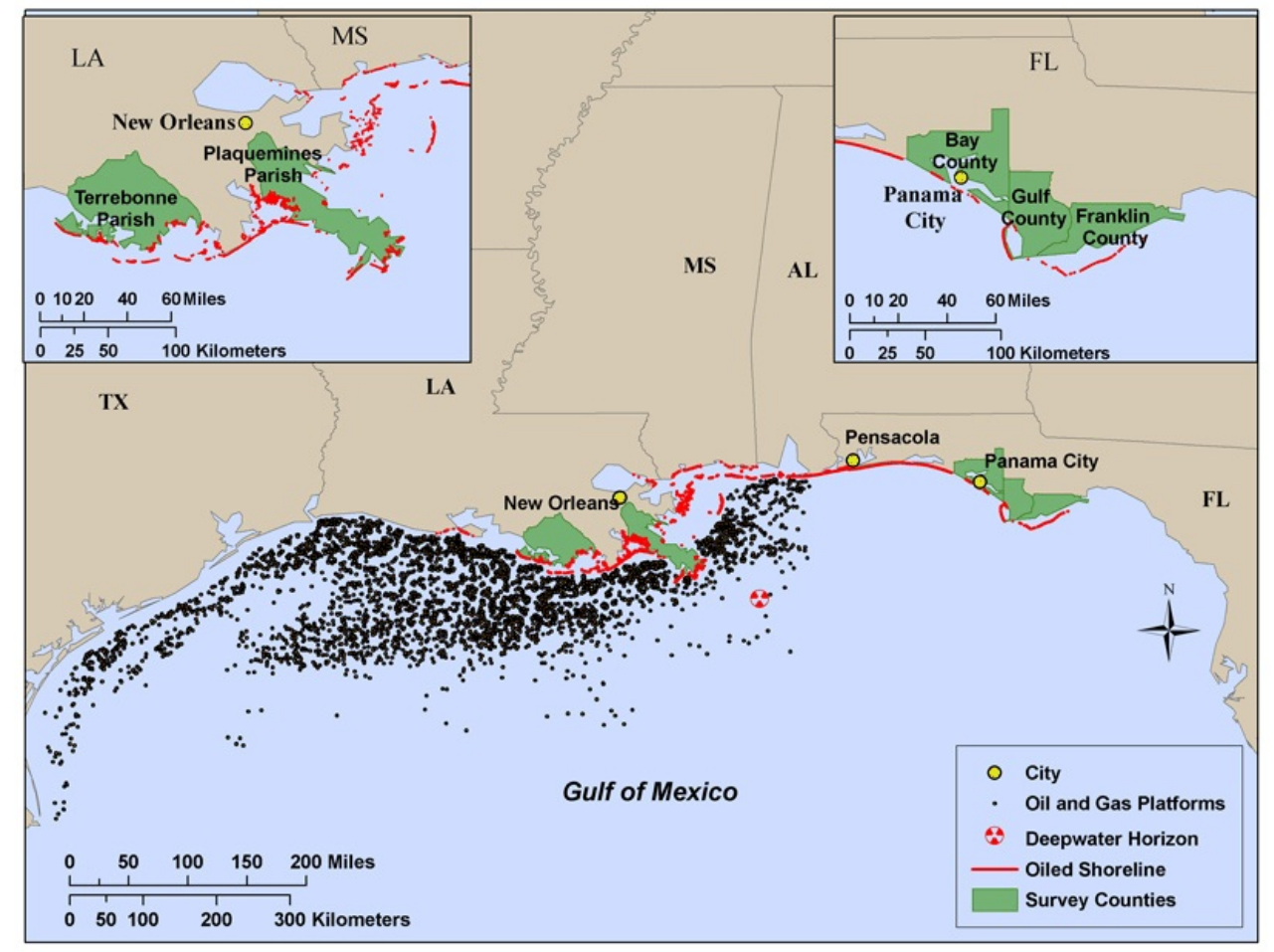

Figure 1: CERA Gulf Coast survey counties and parishes in relation to Deepwater Horizon and other offshore platforms, and to shoreline oiled by the spill.

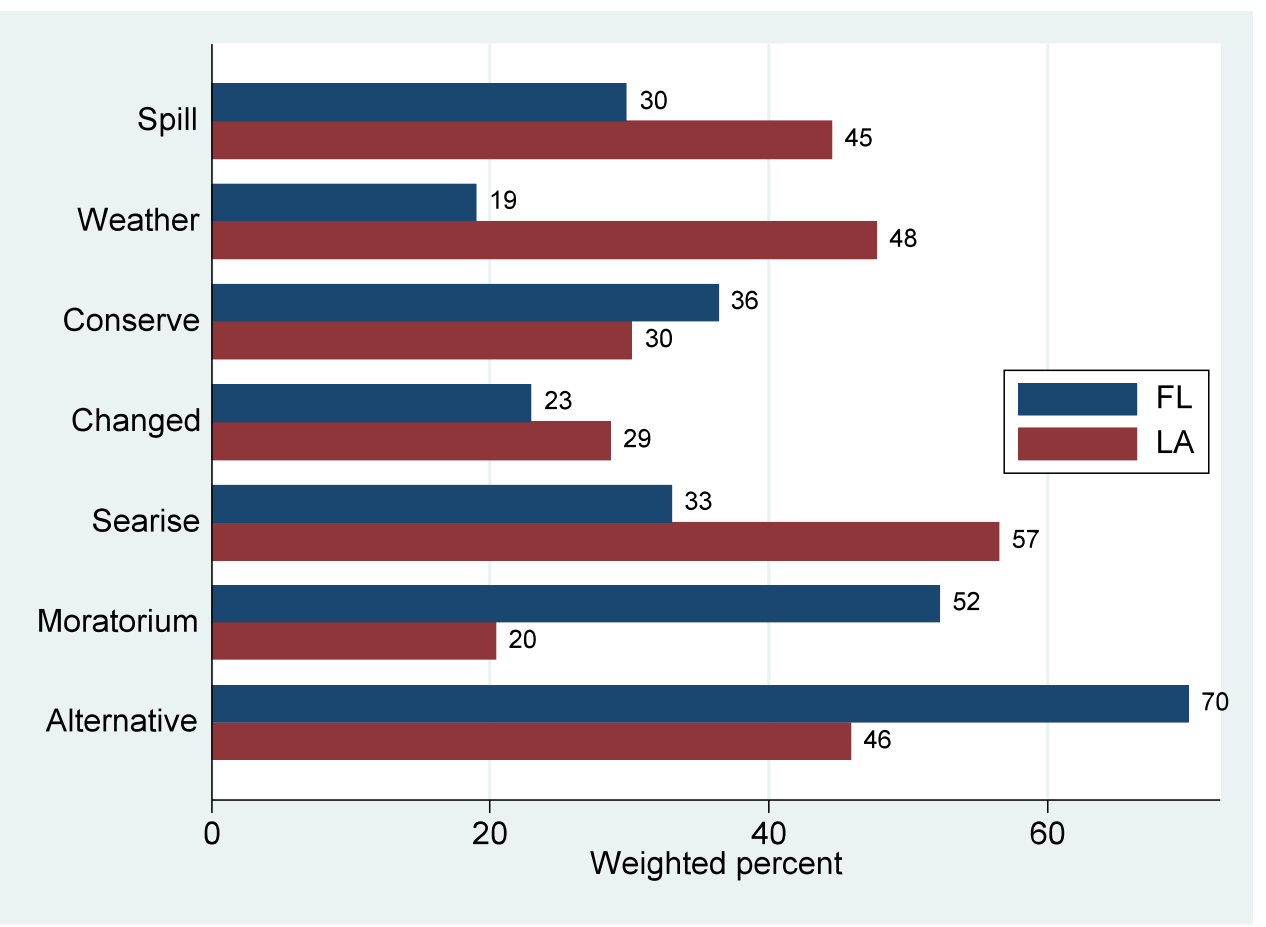

Figure 2: Contrasting views of Gulf Coast Florida and Louisiana residents (variables defined in Table 2). Conserve and changed differences significant at $p<.05$, all others at $p<.001$ (design-based $F$ tests). 